\title{
Flower-like $\mathrm{CeO}_{2} / \mathrm{CoO}$ p-n Heterojuncted Nanocomposites with Enhanced Peroxidase-mimicking Activity for L-Cysteine Sensing
}

Jiajia Lian ${ }^{\dagger}$, Pei Liu ${ }^{\dagger}$, Chunqiao Jin ${ }^{\dagger}$, Qing-Yun Liu*, ${ }^{*}$, Xianxi Zhang and Xiao Zhang§

$\dagger$ College of Chemical and Biological Engineering, Shandong University of Science and Technology, 579 Qianwangang Street, Huangdao District, Qingdao 266590, P. R. China

* College of Chemical and Chemical Engineering, Liaocheng University, 1 Hunan Street, Liaocheng 252059, P. R. China.

$\S$ College of Chemistry and Molecular Engineering, Qingdao University of Science and Technology, 53 Zhengzhou Street, Shibei District, Qingdao 266042, P. R. China

\author{
* Corresponding Author \\ E-mail: qyliu@sdust.edu.cn \\ Tel: +86053286057757
}

Number of SI pages: 9

Number of SI figures: 6

Number of SI tables: 3 


\section{EXPERIMENTAL SECTION}

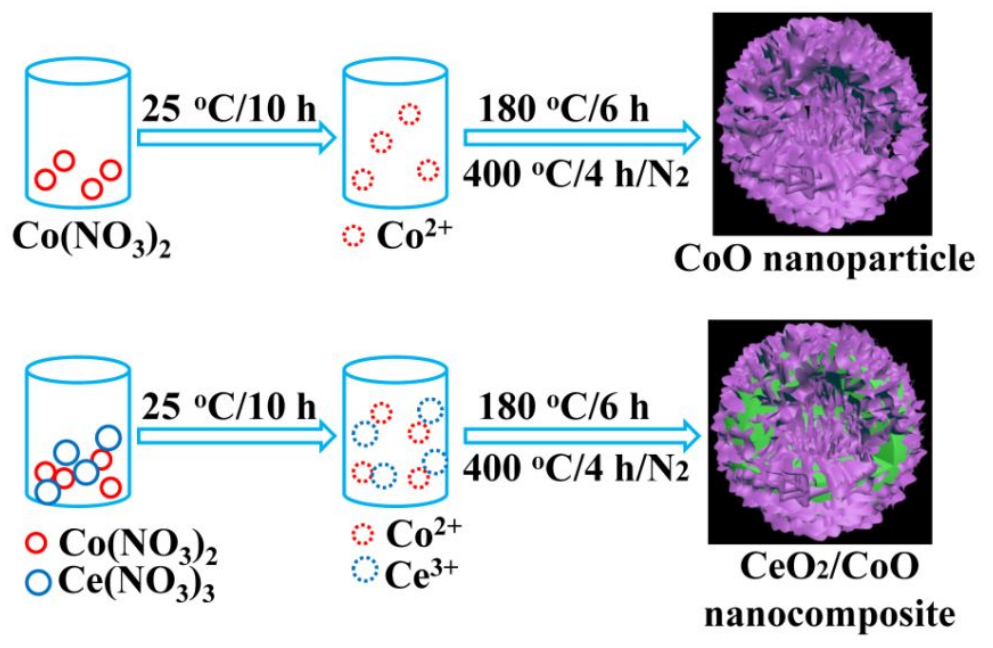

Scheme S1. Synthesis routes of flower-like $\mathrm{CoO}$ NPs and $\mathrm{CeO}_{2} / \mathrm{CoO}$ NCs.

\section{Material characterizations}

Crystal phase characterization was performed on an X-ray diffractometer (XRD, Rigaku D/Max-rB) with a scanning rate of $8^{\circ} \mathrm{min}^{-1}$. The morphology was observed on a scanning electron microscope (SEM, FEI APREO). TEM and HRTEM images were collected on a TEM system (FEI Tecnai G2 F20). The chemical state of surface elements was characterized on an X-ray photoelectron spectroscope (XPS, Thermo ESCALAB 250Xi) with $\mathrm{Al} \mathrm{K \alpha}$ radiation operating at $250 \mathrm{~W}$. After degassing the samples at $120{ }^{\circ} \mathrm{C}$ for $12 \mathrm{~h}, \mathrm{~N}_{2}$ sorption measurements were carried on a specific surface area and porosity analyzer (MIKE Micromeritics ASAP2460). UV-vis diffuse reflection spectra (DRS) were performed on a spectrophotometer (HITACHI UH4150). Mott-Schottky plots and transient photocurrent responses were measured on an electrochemical workstation (Chenhua CHI 660D). A typical three-electrode system was used, including the sample (coated on the ITO glass) as working electrode, a saturated calomel electrode (SCE) as reference electrode, and platinum 
foil as counter electrode. Zeta potentials under different $\mathrm{pH}$ values were determined on a micro-electrophoresis meter (Zhongchen JS94H).

\section{Activity evaluation of $\mathrm{CeO}_{2} / \mathrm{CoO} \mathrm{NCs}$}

The peroxidase-like activities of $\mathrm{CeO}_{2} / \mathrm{CoO}$ samples were evaluated for TMB oxidation with $\mathrm{H}_{2} \mathrm{O}_{2}$ as additive. $200 \mu \mathrm{L}$ of catalyst $\left(0.3 \mathrm{mg} \mathrm{mL} \mathrm{L}^{-1}\right), 200 \mu \mathrm{L}$ of $\mathrm{H}_{2} \mathrm{O}_{2}$ $(200 \mathrm{mM})$ and $200 \mu \mathrm{L}$ of TMB $(2 \mathrm{mM})$ were sequentially injected into $1400 \mu \mathrm{L}$ buffer (pH of 5.0). After reacting for $60 \mathrm{~s}$, the absorbance of the blue solution (ox-TMB) was measured on a UV-vis spectrometer. As a result, the $0.10 \mathrm{CeO}_{2} / \mathrm{CoO} \mathrm{NCs}$ with the highest activity were selected for further investigation. Then the reaction conditions, including $\mathrm{pH}$ and temperature, were optimized to achieve the best effect. The buffers are HAC-NaAC buffer (pH of 3.0-5.0), $\mathrm{NaH}_{2} \mathrm{PO}_{4}-\mathrm{Na}_{2} \mathrm{HPO}_{4}$ buffer (pH of $6.0-8.0$ ) and Tris- $\mathrm{HCl}$ buffer ( $\mathrm{pH}$ of 9.0), respectively. Besides, the repeatability and durability of $0.10 \mathrm{CeO}_{2} / \mathrm{CoO} \mathrm{NCs}$ were also studied.

\section{Kinetic analysis}

Steady-state kinetics of $0.10 \mathrm{CeO}_{2} / \mathrm{CoO} \mathrm{NCs}$ were determined at room temperature $\left(25 \pm 2{ }^{\circ} \mathrm{C}\right)$. In short, $200 \mu \mathrm{L}$ of catalyst $\left(0.3 \mathrm{mg} \mathrm{mL}^{-1}\right), 200 \mu \mathrm{L}$ of $\mathrm{H}_{2} \mathrm{O}_{2}$ and $200 \mu \mathrm{L}$ of TMB were added into $1400 \mu \mathrm{L}$ of buffer ( $\mathrm{pH}$ of 5.0), respectively. Then the absorbance at $652 \mathrm{~nm}$ over reaction time in $120 \mathrm{~s}$ was determined immediately. When varying the $\mathrm{H}_{2} \mathrm{O}_{2}$ from 100 to $1000 \mu \mathrm{M}$, the TMB was kept as 0.2 mM. Similarly, when changing the TMB from 20 to $200 \mu \mathrm{M}$, the $\mathrm{H}_{2} \mathrm{O}_{2}$ was kept as 20 $\mathrm{mM}$. Consequently, a second-order Michaelis-Menten (M-M) equation between variable concentration (C) and initial increase rate of absorbance (v) can be obtained. 
And the maximal reaction rate $\left(\mathrm{V}_{\max }\right)$ and Michaelis constant $\left(\mathrm{K}_{\mathrm{m}}\right)$ can be calculated from the linear relationship between $\mathrm{C}^{-1}$ and $\mathrm{v}^{-1}$. The higher $\mathrm{V}_{\max }$ and smaller $\mathrm{K}_{\mathrm{m}}$ correspond to the better kinetic performance.

\section{Detection of Cys}

A colorimetric sensor $\left(0.10 \mathrm{CeO}_{2} / \mathrm{CoO}+\mathrm{H}_{2} \mathrm{O}_{2}+\mathrm{TMB}\right)$ was constructed for Cys detection. $200 \mu \mathrm{L}$ of nanozymes $\left(0.3 \mathrm{mg} \mathrm{mL}^{-1}\right), 200$ of $\mu \mathrm{L} \mathrm{H}_{2} \mathrm{O}_{2}(200 \mathrm{mM})$ and 200 $\mu \mathrm{L}$ of TMB (2 mM) were sequentially injected into $1400 \mu \mathrm{L}$ of buffer ( $\mathrm{pH}$ of 5.0). After reacting for $60 \mathrm{~s}$ at $37^{\circ} \mathrm{C}, 200 \mu \mathrm{L}$ Cys solution $(50-500 \mu \mathrm{M})$ was added into the above system, and then immediately measured the absorbance. Due to the reducibility of Cys originating from the -SH group, the absorbance difference $(\Delta \mathrm{A})$ before and after adding Cys should be proportional to the Cys concentration. The LOD can be calculated by $3 \mathrm{~s} / \mathrm{k}$, where $\mathrm{s}$ represents the standard deviation of nine blank groups without adding Cys, and $\mathrm{k}$ stands for the slope of the linear relationship between Cys concentrations and the $\Delta \mathrm{A}$ values. The selectivity of this sensor towards Cys was comparatively investigated with various interfering substrates, including cations $\left(\mathrm{NH}_{4}{ }^{+}, \mathrm{Na}^{+}, \mathrm{K}^{+}, \mathrm{Ca}^{2+}, \mathrm{Mg}^{2+}, \mathrm{Zn}^{2+}, \mathrm{Cu}^{2+}, \mathrm{Fe}^{2+}, \mathrm{Fe}^{3+}\right.$ and $\left.\mathrm{Al}^{3+}\right)$, monosaccharides (Glu, Fru and Mal), and amino acids (Arg, His, Leu and Ser). And the final concentration of interfering substrates $(500 \mu \mathrm{M})$ is ten times that of Cys $(50 \mu \mathrm{M})$.

\section{Mechanism analysis}

The free radical trapping experiments were performed on an electron spin resonance (ESR) spectrometer (Bruker EMXmicro-6/1/P/L) with 5, 5-dimethyl-1-pyrroline N-oxide (DMPO) as capture agent at $37{ }^{\circ} \mathrm{C}$. The DMPO-•OH 
signal was detected in water solution. $2 \mathrm{~mL}$ of catalyst $(30 \mu \mathrm{g} \mathrm{mL}-1), 2 \mathrm{~mL}$ of DMPO (50 mM) and $2 \mathrm{~mL}$ of $\mathrm{H}_{2} \mathrm{O}_{2}(20 \mathrm{mM})$ were added into $14 \mathrm{~mL}$ of $\mathrm{HAC}-\mathrm{NaAC}$ buffer ( $\mathrm{pH}$ of 5). Then the reaction system was measured in the dark or under the irradiation of $652 \mathrm{~nm}$ Xenon lamp for different times (1, 3, and $5 \mathrm{~min}$, respectively). Similarly, the DMPO- $\bullet \mathrm{O}_{2}^{-}$signal was determined in a mixture of $90 \mathrm{~mL}$ methanol and $10 \mathrm{~mL}$ water. Finally, combining the obtained ESR results with band-gap structures of $\mathrm{CeO}_{2}$ and $\mathrm{CoO}$, the possible paths for catalyzing the generation of free radicals were proposed here.

\section{RESULTS AND DISSCUSSION}

\section{Material characterization}

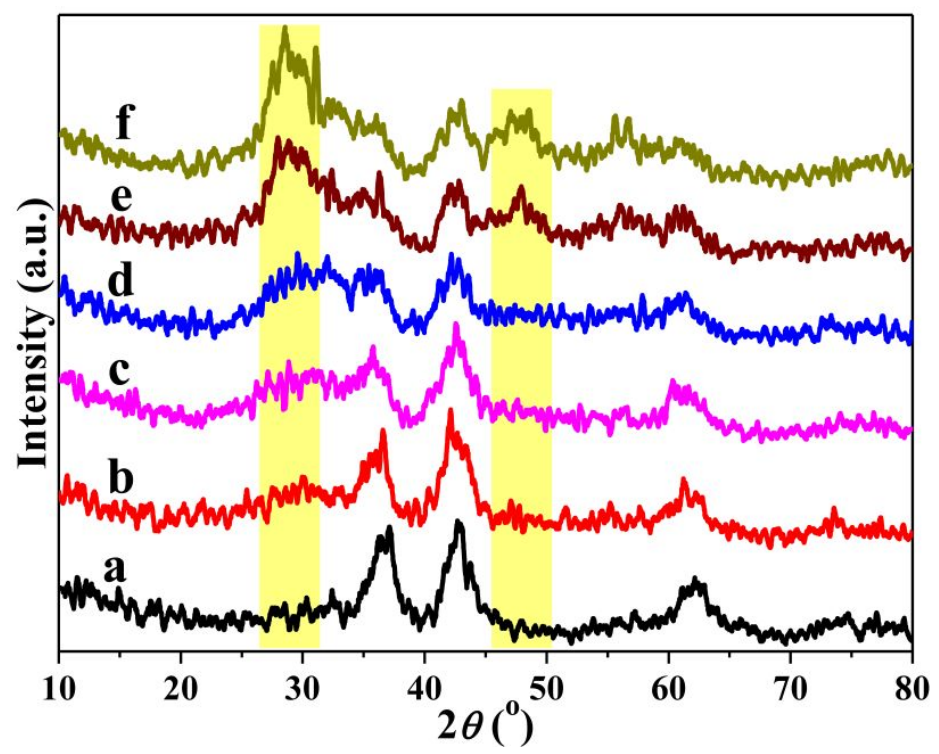

Figure S1. XRD patterns of (a) $0.05 \mathrm{CeO}_{2} / \mathrm{CoO}$; (b) $0.15 \mathrm{CeO}_{2} / \mathrm{CoO}$; (c) $0.20 \mathrm{CeO}_{2} / \mathrm{CoO}$; (d) $0.30 \mathrm{CeO}_{2} / \mathrm{CoO}$; (e) $0.40 \mathrm{CeO}_{2} / \mathrm{CoO}$; (f) $0.50 \mathrm{CeO}_{2} / \mathrm{CoO}$. 

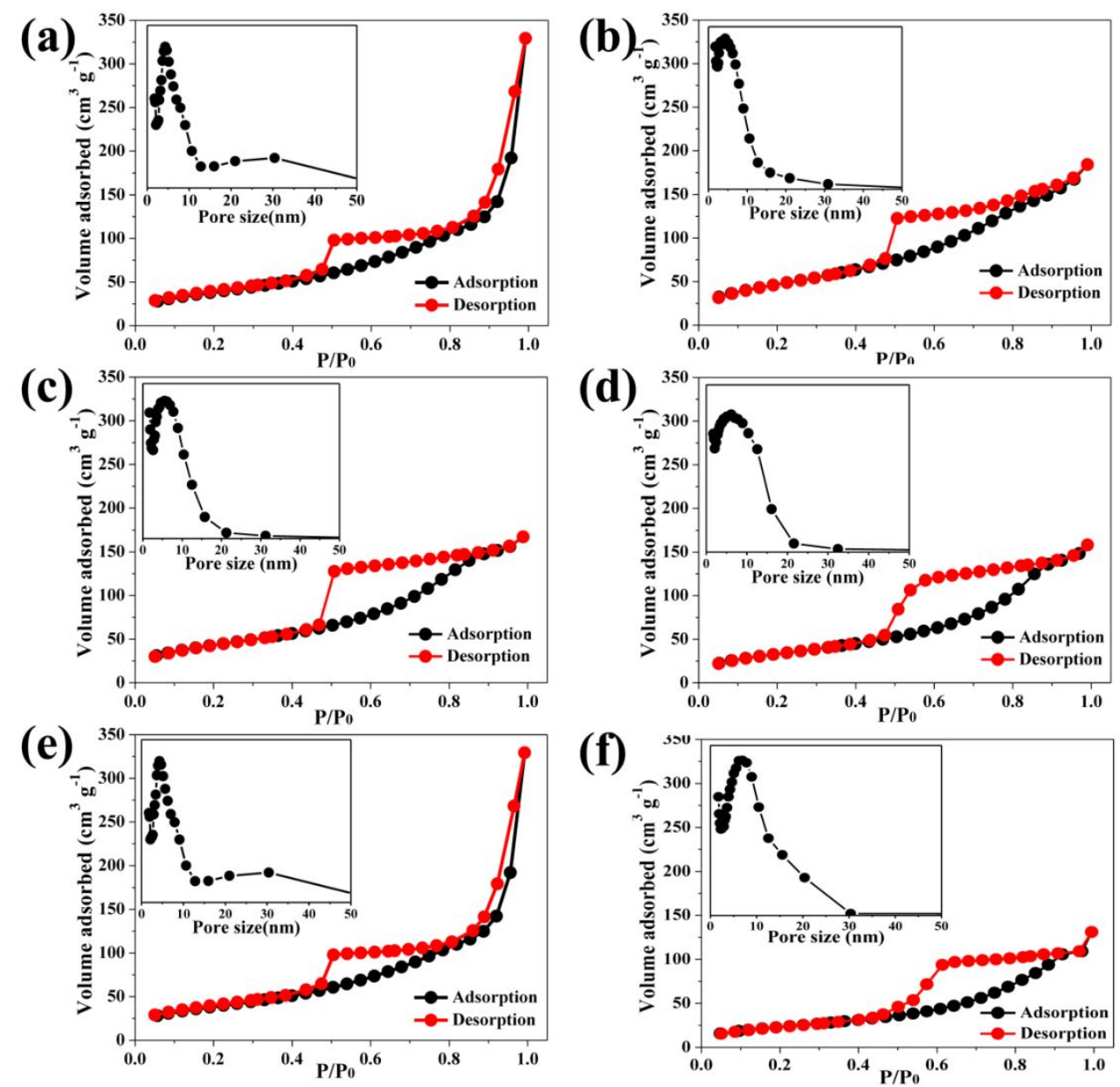

Figure S2. $\mathrm{N}_{2}$ adsorption/desorption curves of (a) $0.05 \mathrm{CeO}_{2} / \mathrm{CoO}$; (b) $0.15 \mathrm{CeO}_{2} / \mathrm{CoO}$; (c) $0.20 \mathrm{CeO}_{2} / \mathrm{CoO}$; (d) $0.30 \mathrm{CeO}_{2} / \mathrm{CoO}$; (e) $0.40 \mathrm{CeO}_{2} / \mathrm{CoO}$ and (f) $0.50 \mathrm{CeO}_{2} / \mathrm{CoO}$. Insets show the corresponding pore size distribution curves.

Table S1. Specific surface area $\left(\mathrm{A}_{\mathrm{BET}}\right)$, pore volume $\left(\mathrm{P}_{\mathrm{V}}\right)$ and average pore size $\left(\mathrm{P}_{\mathrm{S}}\right)$ of $\mathrm{CeO}_{2} \mathrm{NPs}$, $\mathrm{CoO}$ NPs and $\mathrm{xCeO}_{2} / \mathrm{CoO}$ NCs.

\begin{tabular}{cccc}
\hline Samples & $\mathrm{A}_{\mathrm{BET}}\left(\mathrm{cm}^{2} / \mathrm{g}\right)$ & $\mathrm{P}_{\mathrm{V}}\left(\mathrm{cm}^{3} / \mathrm{g}\right)$ & $\mathrm{P}_{\mathrm{S}}(\mathrm{nm})$ \\
\hline $\mathrm{CeO}_{2}$ & 11.5028 & 0.025238 & 8.0580 \\
$\mathrm{CoO}$ & 216.1638 & 0.882486 & 14.4553 \\
$0.05 \mathrm{CeO}_{2} / \mathrm{CoO}$ & 140.3493 & 0.514307 & 13.7126 \\
$0.10 \mathrm{CeO}_{2} / \mathrm{CoO}$ & 158.2515 & 0.495605 & 11.2511 \\
$0.15 \mathrm{CeO}_{2} / \mathrm{CoO}$ & 174.2334 & 0.29325 & 6.1701 \\
$0.20 \mathrm{CeO}_{2} / \mathrm{CoO}$ & 157.0756 & 0.255955 & 6.4138 \\
$0.30 \mathrm{CeO}_{2} / \mathrm{CoO}$ & 123.7093 & 0.249283 & 7.2337 \\
$0.40 \mathrm{CeO}_{2} / \mathrm{CoO}$ & 99.6368 & 0.22148 & 8.0727 \\
$0.50 \mathrm{CeO}_{2} / \mathrm{CoO}$ & 86.1071 & 0.205761 & 8.6995 \\
\hline
\end{tabular}


Table S2. Atomic ratios of surface elements on $\mathrm{CoO} N \mathrm{Ns}$ and $0.10 \mathrm{CeO}_{2} / \mathrm{CoO} \mathrm{NCs}$.

\begin{tabular}{cccc}
\hline \multirow{2}{*}{ Samples } & $\mathrm{O}_{\mathrm{a}}($ at.\%) & $\mathrm{O}_{\mathrm{b}}($ at.\%) & $\mathrm{O}_{\mathrm{c}}$ (at.\%) \\
\cline { 2 - 4 } & $529.8 \mathrm{eV}$ & $531.2 \mathrm{eV}$ & $531.7 \mathrm{eV}$ \\
\hline $\mathrm{CoO}$ & 43.2 & 29.0 & 27.8 \\
$0.10 \mathrm{CeO}_{2} / \mathrm{CoO}$ & 49.9 & 40.1 & 10.0 \\
\hline
\end{tabular}

\section{Catalytic activity}

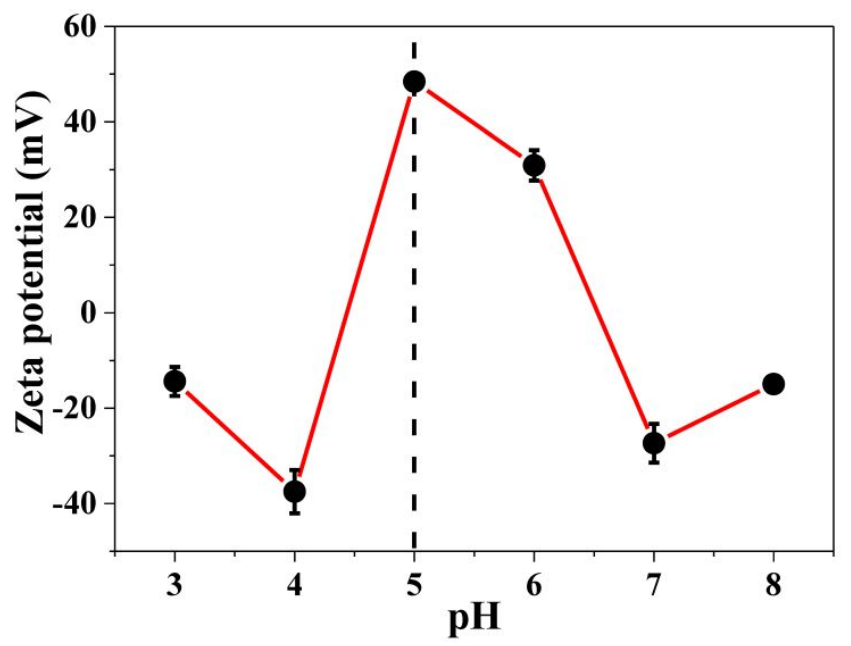

Figure S3. Influence of $\mathrm{pH}$ on the zeta potential of $0.10 \mathrm{CeO}_{2} / \mathrm{CoO} \mathrm{NCs}$.
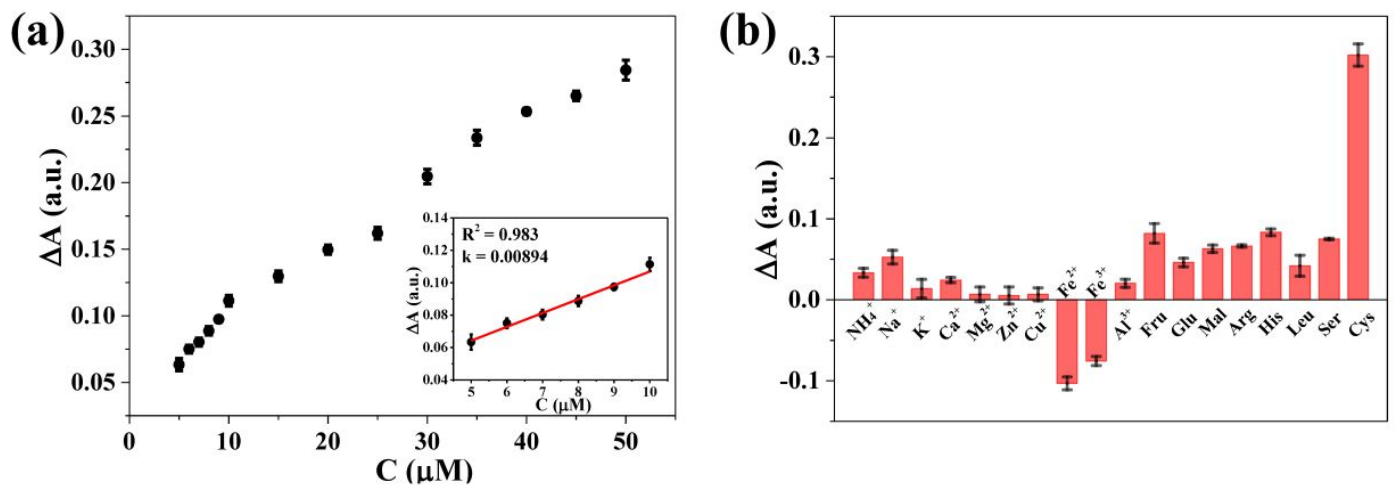

Figure S4. Reproducibility for the sensing of Cys: (a) $\Delta \mathrm{A}$ responses of $0.10 \mathrm{CeO}_{2} / \mathrm{CoO}+\mathrm{H}_{2} \mathrm{O}_{2}+$ TMB system at $652 \mathrm{~nm}$ toward Cys concentration ranging from 5 to $50 \mu \mathrm{M}$, inset is the linear fitting curve from 5 to $10 \mu \mathrm{M}$; (b) Selectivity of $0.10 \mathrm{CeO}_{2} / \mathrm{CoO}$ NCs towards Cys $(50 \mu \mathrm{M})$ in comparison with various interferences $(500 \mu \mathrm{M})$. 

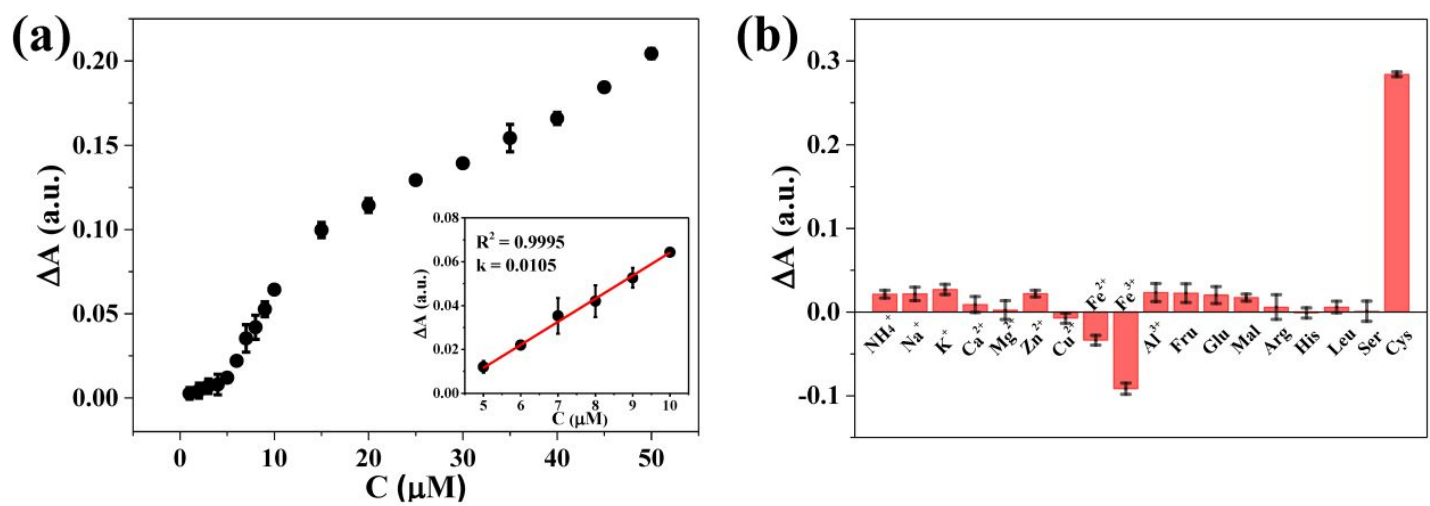

Figure S5. (a) $\triangle \mathrm{A}$ responses of $\mathrm{CoO}+\mathrm{H}_{2} \mathrm{O}_{2}+\mathrm{TMB}$ system at $652 \mathrm{~nm}$ toward Cys concentration ranging from 5 to $50 \mu \mathrm{M}$, inset is the linear fitting curve from 5 to $10 \mu \mathrm{M}$; (b) Selectivity of CoO NPs towards Cys $(50 \mu \mathrm{M})$ in comparison with various interferences $(500 \mu \mathrm{M})$.

Table S3. Comparison of the analytical parameters of $0.10 \mathrm{CeO}_{2} / \mathrm{CoO}$ NCs with published reports.

\begin{tabular}{llllll}
\hline Samples & Method & Time & Range & LOD & Ref \\
\hline $0.10 \mathrm{CeO}_{2} / \mathrm{CoO} N C s$ & Colorimetric & $60 \mathrm{~s}$ & $5-10 \mu \mathrm{M}$ & $3.71 \mu \mathrm{M}$ & This work \\
$\mathrm{CoO} \mathrm{NPs}$ & Colorimetric & $60 \mathrm{~s}$ & $5-10 \mu \mathrm{M}$ & $6.01 \mu \mathrm{M}$ & This work \\
$\mathrm{Gd}(\mathrm{OH})_{3} \mathrm{NRs}$ & Colorimetric & $10 \mathrm{~min}$ & $0.2-70 \mu \mathrm{M}$ & $2.6 \mu \mathrm{M}$ & 1 \\
$\mathrm{CuMnO}_{2} \mathrm{NFs}$ & Colorimetric & $15 \mathrm{~min}$ & $25-300 \mu \mathrm{M}$ & $11.26 \mu \mathrm{M}$ & 2 \\
$\mathrm{Co}_{4} \mathrm{~S}_{3} \mathrm{NPs}$ & Colorimetric & $2 \mathrm{~min}$ & $20-100 \mathrm{mM}$ & $10 \mathrm{mM}$ & 3 \\
Lucigenin-CD & Fluorescence & - & $10-100 \mu \mathrm{M}$ & $8.8 \mu \mathrm{M}$ & 4 \\
AuNCs-AuNPs & Fluorescence & $6 \mathrm{~min}$ & $1.5-35.0 \mu \mathrm{M}$ & $1.4 \mu \mathrm{M}$ & 5 \\
$\mathrm{Cu}^{2+}$-phen-dione & Electrochemical & - & $10-32,344 \mu \mathrm{M}$ & $2.0 \mu \mathrm{M}$ & 6 \\
$@$ ERGO/GC & & & & & \\
Poly(p-coumaric & Electrochemical & - & $50-1000 \mu \mathrm{M}$ & $3.6 \mu \mathrm{M}$ & 7 \\
acid)/MWNT/GC & & & & & \\
\hline
\end{tabular}

\section{REFERENCES}

(1) Singh, M.; Weerathunge, P.; Liyanage, P.; Mayes, E.; Ramanathan, R.; Bansal, V. Competitive inhibition of the enzyme-mimic activity of Gd-based nanorods toward highly specific colorimetric sensing of L-Cysteine. Langmuir 2017, 33 (38), 10006-10015, 10.1021/acs.langmuir.7b01926.

(2) Chen, Y.; Chen, T.; Wu, X.; Yang, G. $\mathrm{CuMnO}_{2}$ nanoflakes as pH-switchable catalysts with multiple enzyme-like activities for cysteine detection. Sensor. Actuat. 
B-Chem. 2019, 279, 374-384, 10.1016/j.snb.2018.09.120.

(3) Wang, J.; Wang, Y.; Zhang, D. Exploring the bactericidal performance and application of novel mimic enzyme $\mathrm{Co}_{4} \mathrm{~S}_{3}$. J. Colloid Interface Sci. 2020, 561, 327-337, 10.1016/j.jcis.2019.10.110.

(4) Wang, C.; Lan, Y.; Yuan, F.; Fereja, T.; Lou, B.; Han, S.; Li, J.; Xu, G. Chemiluminescent determination of L-cysteine with the lucigenin-carbon dot system. Microchim. Acta 2019, 187 (1), 50, 10.1007/s00604-019-3965-9.

(5) Li, X.; Qiao, J.; Li, Z.; Qi, L. Fluorescence turn-off-on for highly selective detection of serum L-Cysteine based on AuNCs-AuNPs ensembles. Analyst 2020, 145, 2233-2237, 10.1039/c9an02495f.

(6) Kumar, D.; Baynosa, M. L.; Shim, J. $\mathrm{Cu}^{2+}-1,10-$ phenanthroline-5,6-dione@ electrochemically reduced graphene oxide modified electrode for the electrocatalytic determination of L-cysteine. Sensor. Actuat. B-Chem. 2019, 293, 107-114, 10.1016/j.snb.2019.04.122.

(7) Ziyatdinova, G.; Kozlova, E.; Budnikov, H. Selective electrochemical sensor based on the electropolymerized p-coumaric acid for the direct determination of L-Cysteine. Electrochim. Acta 2018, 270, 369-377, 10.1016/j.electacta.2018.03.102. 